\title{
Convenient one-step synthesis of 5-carboxy-seminaphthofluoresceins
}

Hammershøj, Peter; Thyhaug, Erling; Harris, Pernille; Ek, Pramod Kumar; Andresen, Thomas Lars; Clausen, Mads Hartvig

Published in:

Tetrahedron Letters

Link to article, DOI:

10.1016/j.tetlet.2017.03.028

Publication date:

2017

Document Version

Peer reviewed version

Link back to DTU Orbit

Citation (APA):

Hammershøj, P., Thyhaug, E., Harris, P., Ek, P. K., Andresen, T. L., \& Clausen, M. H. (2017). Convenient onestep synthesis of 5-carboxy-seminaphthofluoresceins. Tetrahedron Letters, 58(16), 1611-1615.

https://doi.org/10.1016/j.tetlet.2017.03.028

\section{General rights}

Copyright and moral rights for the publications made accessible in the public portal are retained by the authors and/or other copyright owners and it is a condition of accessing publications that users recognise and abide by the legal requirements associated with these rights.

- Users may download and print one copy of any publication from the public portal for the purpose of private study or research.

- You may not further distribute the material or use it for any profit-making activity or commercial gain

- You may freely distribute the URL identifying the publication in the public portal

If you believe that this document breaches copyright please contact us providing details, and we will remove access to the work immediately and investigate your claim 


\title{
Convenient One-Step Synthesis of 5-Carboxy-Seminaphthofluoresceins
}

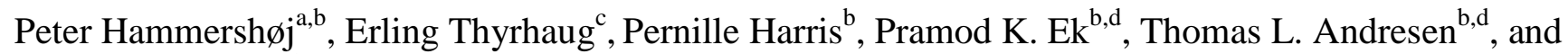 \\ Mads H. Clausen ${ }^{\mathrm{a}, \mathrm{b}}$ * \\ ${ }^{a}$ Department of Chemistry, Technical University of Denmark, Building 207,2800 Kgs. Lyngby, Denmark \\ ${ }^{b}$ Center for Nanomedicine and Theranostics, Technical University of Denmark, 2800 Kgs. Lyngby, Denmark \\ ${ }^{c}$ Department of Chemical Physics, Lund University, Getingevägen 60, 22241 Lund, Sweden \\ ${ }^{d}$ Department of Micro- and NanoTechnology, DTU NanoTech, Technical University of Denmark, Building 423,2800 Kgs. Lyngby, Denmark
}

\section{ARTICLE INFO}

\section{ABSTRACT}

\section{Article history:}

\section{Received}

Received in revised form

Accepted

Available online
The one-step synthesis and characterization of a series of regioisomerically pure 5-carboxyseminaphthofluoresceins (5-carboxy-SNAFLs) is reported. The optical properties were determined in aqueous buffer at around biological $\mathrm{pH}$, and highly $\mathrm{pH}$ sensitive, large Stokesshift fluorophores with emission in the deep-red to near-infrared region were identified.

2009 Elsevier Ltd. All rights reserved.

\section{Keywords:}

5-carboxy-seminaphthofluoresceins

near-infrared-emitter

one-step synthesis

enhanced Stokes shifts

\section{Introduction}

The development and characterization of functional red and near-infrared-emitting (NIR) organic dyes with available anchoring sites is of great current interest especially in fields such as biomedicine, biochemistry, and soft-matter science. ${ }^{1-4}$ Due to the low cost, reliability, and low invasiveness of fluorescent techniques in, for example, diagnostics and imaging, there is an ongoing search for new and better dyes. The importance placed on red-NIR dyes in this context is primarily due to the near-absence of biological autofluorescence in this spectral range, and the large penetration depth of NIR light in biological tissue. ${ }^{5-7}$

5- and 6-carboxy-fluorescein are well-known functional dyes, with strongly $\mathrm{pH}$ sensitive optical properties and anchoring sites for target conjugation, and are suitable for a wide range of biological and materials science applications. ${ }^{8,9}$ The long history of their chemical modification of these dyes has broadened the scope of their use, however a fundamental limitation is the relatively high-energy emission, centered at approximately 520 $\mathrm{nm}$. Developing robust approaches to substantially lowering the emission energy of this otherwise excellent class of dyes has thus been a topic of significant interest. ${ }^{5-15}$ One such approach has been to extend the fluorescein scaffold with additional benzoid rings to one or both sides, yielding seminaphthofluorescein (SNAFL) or naphthofluorescein respectively (Fig. 1). These represent fluorescein analogs of the well-known structurally related seminaphthorhodafluors (SNARF) rhodamine derivatives (see Fig. 1).

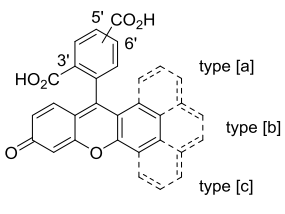

SNAFL

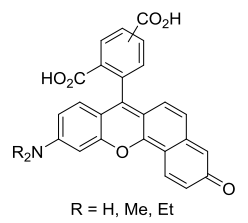

SNARF

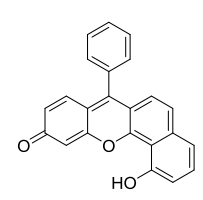

SNAFR
Figure 1. Structure of type [a], [b] and [c] seminaphthofluorescein (SNAFL), seminaphthorhodafluor (SNARF) and seminaphthofluorone (SNAFR).

Furthermore, as a class of dyes they show tunable wavelengths, with emission ranging from the deep-red to the near-infrared region..$^{5-13}$ This range of emission properties appear due to its dependence on both the geometry of the conjugated system and the position of the hydroxy group on the naphthalene moiety. ${ }^{5-7,13}$ The benzene unit can in general be positioned in three different ways termed type [a], [b] and [c] (Fig. 1). The importance of the benzannulation position has been studied both by semiempirical calculations and by synthesizing a large range of regioisomers of closely related seminaphthofluorene (SNAFR) derivatives. ${ }^{13}$ The structure of carboxy-SNAFLs diverges from SNAFRs by two additional carboxylic acids at the 3' and 5' or 6' 
positions (Fig. 1). SNAFR derivatives thus lack the obvious linking sites provided by the 5' or 6' carboxylic acids. In general the synthesis of seminaphtho- and naphthofluorescein requires multiple steps and, in the cases where a carboxylic acid is present at the $5^{\prime}$ or $6^{\prime}$ positions, mixtures of the two regioisomers are formed. ${ }^{16}$ The fluorescence quantum yields are typically low in aqueous solutions $(<9 \%)$. In most cases an increase in quantum yield, Stokes shifts and maximum absorption/emission peak is observed in organic solvents. ${ }^{6}$

In the present work we report the synthesis and optical properties of a number of 5-carboxy-SNAFL derivatives. The general synthetic approach uses the 5-carboxy-fluorescein scaffold and extends it by a benzene unit, enabling the use of well-known chemistry from 5-carboxy-fluorescein to synthesize the newly developed dyes. Depending on the direction of benzannulation, and in particular the position of the naphthol, the compounds exhibit deep-red to NIR emission with large Stokes shifts and $\mathrm{p} K_{\mathrm{a}}$ values around 8 .

\section{Results and Discussion}
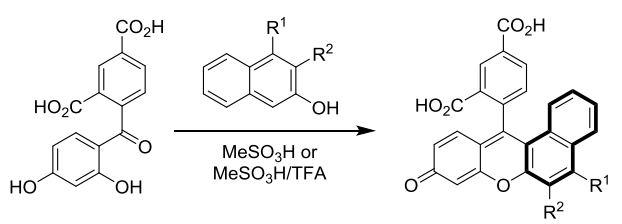

type [a]

1

$$
2 \mathrm{R}^{1}=\mathrm{OH}, \mathrm{R}^{2}=\mathrm{H}
$$

$$
3 \mathrm{R}^{1}=\mathrm{H}, \mathrm{R}^{2}=\mathrm{OH}
$$
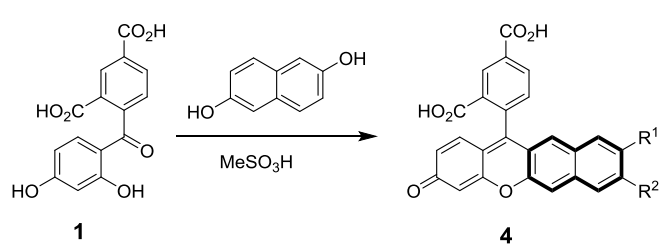

type [b]

1
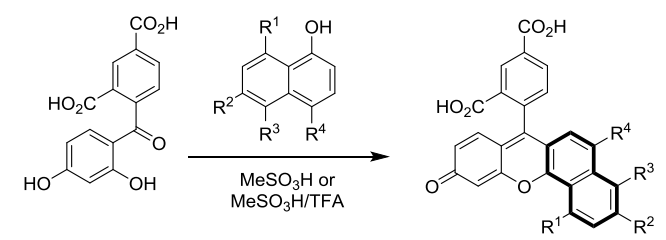

type [c]

1

$5 \mathrm{R}^{1}=\mathrm{H}, \mathrm{R}^{2}=\mathrm{H}, \mathrm{R}^{3}=\mathrm{H}, \mathrm{R}^{4}=\mathrm{OH}$

$6 R^{1}=H, R^{2}=H, R^{3}=O H, R^{4}=H$

$7 \mathrm{R}^{1}=\mathrm{H}, \mathrm{R}^{2}=\mathrm{OH}, \mathrm{R}^{3}=\mathrm{H}, \mathrm{R}^{4}=\mathrm{H}$

$8 R^{1}=\mathrm{OH}, \mathrm{R}^{2}=\mathrm{H}, \mathrm{R}^{3}=\mathrm{H}, \mathrm{R}^{4}=\mathrm{H}$

Scheme 1. Synthesis of type [a], [b] and [c] 5-carboxySNAFLs 2-8.

The synthetic approach described herein is based on our previous work, where we reported the condensation between 2and 4-(2,4-dihydroxybenzoyl)isophthalic acid and a number of different resorcinol derivatives. ${ }^{9,17}$ The reaction between electronrich dihydroxynaphthalene (naphthalene-1,3-diol) was found to proceed in a high yield and could easily be purified by precipitation to yield 5-carboxy-SNAFL-2.

To further investigate the scope of the reaction, the condensation between 4-(2,4-dihydroxybenzoyl)isophthalic acid (1) in methanesulfonic acid (or a 1:1 mixture with TFA), and the 10 regioisomers of dihydroxynaphthalene (Scheme 1 and Table 1) was examined. Through this procedure, 7 new benzannulated 5-carboxy-SNAFLs (2-8) were produced. ${ }^{18,19}$ To the best of our knowledge this constitutes the largest set of type [c] isomers of SNAFL (5-8) with the hydroxyl group located at 4 different positions. $^{6}$ 2,7-Dihydroxynaphthalene gave a $1: 1$ mixture of regioisomeric 5-carboxy-SNAFLs (LCMS, not shown), however, the isomers were not separated. Only trace amounts of the desired product were observed using 1,2- and 1,7-dihydroxynaphthalene (LCMS).
Table 1. Yields, solvents and reaction times.

\begin{tabular}{|l|l|l|l|}
\hline 5 -Carboxy-SNAFL & Yield (\%) & Solvent & Time $(\mathrm{h})$ \\
\hline $2^{\mathrm{a}}$ & 79 & $\mathrm{MeSO}_{3} \mathrm{H}$ & 1 week $^{\mathrm{c}}$ \\
\hline 3 & 29 & $\mathrm{MeSO}_{3} \mathrm{H} /$ TFA & 24 \\
\hline 4 & 80 & $\mathrm{MeSO}_{3} \mathrm{H}$ & 12 \\
\hline 5 & 74 & $\mathrm{MeSO}_{3} \mathrm{H} /$ TFA & 20 \\
\hline 6 & 75 & $\mathrm{MeSO}_{3} \mathrm{H}$ & 3 \\
\hline 7 & 79 & $\mathrm{MeSO}_{3} \mathrm{H} /$ TFA & 24 \\
\hline 8 & $59^{\mathrm{b}}$ & $\mathrm{MeSO}_{3} \mathrm{H} /$ TFA & 2 \\
\hline
\end{tabular}

${ }^{a}$ Ref. 9. ${ }^{b}$ Based on limiting dihydroxynaphthalene. ${ }^{c}$ Not tested using TFA.

X-ray quality crystals of carboxy-SNAFL-5 co-crystallized with acetic acid were obtained (Fig. 2). The conjugated system is twisted so that the additional benzoid moiety is tilted an angle of $9.88(1)^{\circ}$ with respect to the central ring. The angle between the plane of the central ring and the phthalic acid ring is $79.91(6)^{\circ}$.

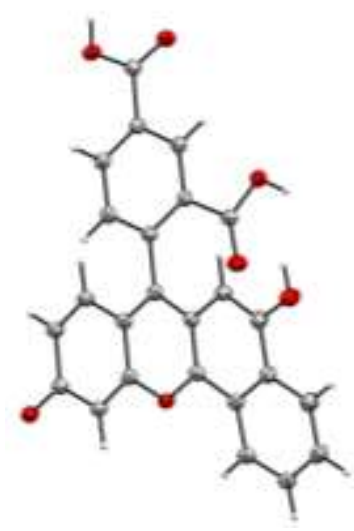

Figure 2. Single crystal X-ray structure of carboxy-SNAFL-5 (cocrystallizes with one acetic acid molecule which has been omitted for clarity).

One of the great strengths of fluorescein dyes is their potential application in biological sensing and imaging. It is thus of primary importance to characterize the SNAFL derivatives in aqueous buffer near biological $\mathrm{pH}$. The photophysical properties of the dyes in a standard aqueous phosphate/citric acid buffer containing $1 \%$ DMSO were evaluated and their optical properties summarized in Table 2, where the properties of 5-carboxySNAFL-2, are provided for comparison ${ }^{9}$.

In direct analogy to carboxy-fluoresceins, the carboxy-SNAFL dyes exist in one of two forms around biological $\mathrm{pH}$ : a "naphthol" form, and the corresponding naphtholate, called "oxyanion" in the following. The relative population of these two species at a given $\mathrm{pH}$ is strongly dependent on the structure of the dye. The absorption spectra of both naphthol and oxyanion species for all dyes are shown in Fig. 3.

In mildly acidic buffer, the naphthalene orientation and hydroxyl substitution pattern appears to have only a modest influence on the spectral properties. Under these conditions the main absorption band appears with moderate oscillator strength at approximately $520 \mathrm{~nm}$. The vibrational progression is clearly resolved, and overall the spectral structure is similar to what would be expected from rigid aromatic molecules, e.g. xanthenes. The spectral similarity between these species is presumably a result of identical overall extent of the $\pi$ conjugated system, and that the hydroxyl group only weakly perturbs the electronic structure. 


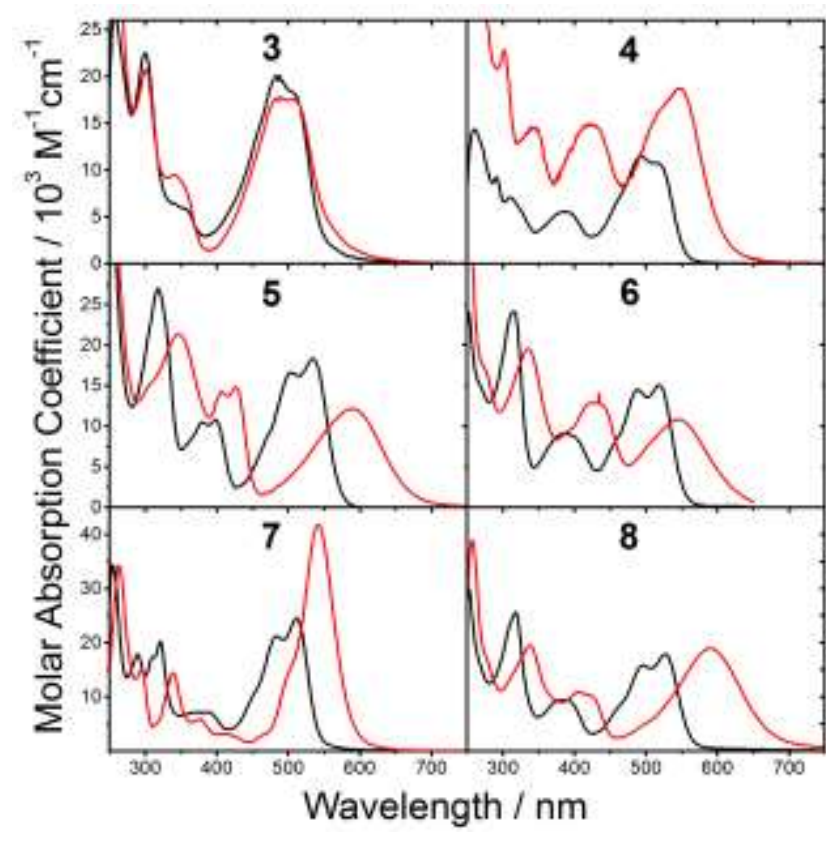

Figure 3. Absorption spectra in aqueous buffer containing 1\% DMSO at pH 6 (black) and pH 11 (red).

As the $\mathrm{pH}$ is increased, the naphthol moiety is deprotonated, resulting in a red-shift of the absorption band, a loss of vibrational structure, and an increase in oscillator strength. This behavior is similar to that observed for carboxy-fluorescein derivatives. Clear isosbestic points are observed during the $\mathrm{pH}$ titration of the dyes, implying a simple two-species equilibrium over the $\mathrm{pH}$ range from approximately 5 to 10 . We note that at very low $\mathrm{pH}$ the dyes exist largely as a colorless, likely lactone form, again analogous to carboxy-fluoresceins.

The extent of deprotonation at a given $\mathrm{pH}$ appears to depend on whether the dye can support a charge-resonance between the two oxygen substituents. In both $\mathbf{7}$ and $\mathbf{8}$ such charge-resonances are possible, effectively stabilizing the deprotonated form, which is reflected in a relatively low $\mathrm{p} K_{\mathrm{a}}$ value. In contrast, $\mathbf{4}$ has a $\mathrm{p} K_{\mathrm{a}}$ value of approximately 9 , while it does not appear to be possible to deprotonate 3 in aqueous media as partial decomposition of the dye to a colorless product starts around $\mathrm{pH} 13$. Transitions to charge-resonant states generally appear red-shifted, with the magnitude of the shift being related to the length of the resonance system involved. This is exemplified by, for example, the spectral behavior of cyanines. As $\mathbf{8}$ has a longer conjugated resonant system than $\mathbf{7}$, a stronger red-shift is predicted, in agreement with the spectra in Fig. 3.

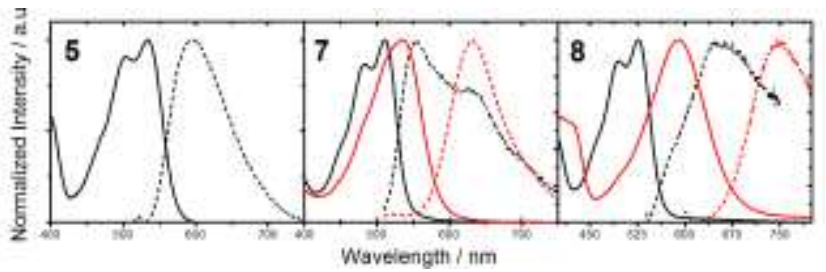

Figure 4. Normalized absorption (full line) and emission (dotted line) of 5, 7 and $\mathbf{8}$ in aqueous buffer at pH 6 (black) and pH 11 (red). See text for details.

The emission properties of the dyes investigated herein are surprisingly diverse. Neither $\mathbf{3}$, nor $\mathbf{4}$, nor $\mathbf{6}$ fluoresce appreciably in aqueous solution, regardless of $\mathrm{pH}$, which is unexpected, considering the close structural analogy to the highly efficient carboxy-fluorescein fluorophores. The dye $\mathbf{5}$ and the chargeresonant species $\mathbf{7}$ and $\mathbf{8}$ are emissive in aqueous buffer, however, with $\mathbf{5}$ and $\mathbf{7}$ being moderately strong red emitters and $\mathbf{8}$ being a weak near-infrared emitter. The normalized absorption and emission spectra of these species are shown in Fig. 4. Compound $\mathbf{5}$ emits under acidic and neutral conditions, but is essentially non-emitting in alkaline media. Both charge-resonant species show substantially higher quantum yields and large Stokes shift in alkaline solution, however, the overall yield of $\mathbf{7}$ is in excess of 10 times larger than that of $\mathbf{8}$ regardless of environment. We note that $\mathbf{7}$ appear to be a rather strong excitedstate proton donor. As a result, there is a noticeable contribution to the spectrum at approximately $630 \mathrm{~nm}$ from the oxyanion form even at relatively low $\mathrm{pH}$.

\section{Conclusion}

The synthesis, structure, and optical properties of a series of 5'-carboxy SNAFL dyes. The synthetic approach is quite flexible, and may be generalized to yield a broad range of "fluorescein-type" dyes with diverse optical properties. The SNAFL dyes are water soluble and can be conjugated to a variety of targets using standard amide-coupling protocols or by subsequent formation of the $N$-hydroxysuccinimide ester. Of the SNAFL species investigated, the charge-resonant compounds 7 and $\mathbf{8}$ prove most interesting due to reasonably efficient fluorescence. Dye $\mathbf{7}$ in particular displayed emission of comparable strength to many red/NIR emitting dyes, and may find use in biological sensing due to its relatively low $\mathrm{p} K_{\mathrm{a}}$ and strong optical response to $\mathrm{pH}$. The emission of $\mathbf{8}$ is comparatively weak, and in practice only appreciable in a weakly alkaline environment. The NIR emission and large Stokes shift of the oxyanion form however results in a dye that is highly resistant to autofluorescence background and scattering. It might therefore, despite its relatively low emission yield, prove useful in applications where background rejection rather than excitation/emission power is the major concern.

Table 2. Optical properties of 5-carboxy-SNAFLs 3-8

\begin{tabular}{|c|c|c|c|c|c|c|c|c|c|}
\hline SNAFL & $\begin{array}{c}\lambda_{\max }{ }^{\text {abs }}(\mathrm{nm}) \\
\text { Naphthol }^{\mathrm{d}}\end{array}$ & $\begin{array}{c}\varepsilon_{\max } \\
\left(\mathrm{M}^{-1} \mathrm{~cm}^{-1}\right)\end{array}$ & $\begin{array}{l}\lambda_{\max }^{\text {abs }}(\mathrm{nm}) \\
\text { Oxyanion }^{\mathrm{e}}\end{array}$ & $\begin{array}{c}\varepsilon_{\max } \\
\left(\mathrm{M}^{-1} \mathrm{~cm}^{-1}\right)\end{array}$ & $\begin{array}{c}\lambda_{\max }^{\mathrm{em}}(\mathrm{nm}) \\
\text { Naphthol }^{\mathrm{d}}\end{array}$ & $\Phi$ & $\begin{array}{l}\lambda_{\max }^{\mathrm{em}}(\mathrm{nm}) \\
\text { Oxyanion }^{\mathrm{e}}\end{array}$ & $\Phi$ & $\mathrm{p} K_{\mathrm{a}}$ \\
\hline $2^{a}$ & 508 & - & - & - & 550 & 0.11 & - & - & 11 \\
\hline 3 & 508 & 20300 & $-{ }^{c}$ & $-{ }^{c}$ & $-{ }^{b}$ & - & $-{ }^{b}$ & - & $>10^{\mathrm{c}}$ \\
\hline 4 & 517 & 20000 & 548 & 32500 & $-{ }^{\mathbf{b}}$ & - & $-{ }^{b}$ & - & 9.1 \\
\hline 5 & 534 & 17100 & 590 & 12200 & 595 & 0.02 & $-{ }^{b}$ & - & 8.5 \\
\hline 6 & 518 & 16200 & 545 & 11000 & $-{ }^{b}$ & - & $-{ }^{b}$ & - & 8.5 \\
\hline 7 & 512 & 24500 & 538 & 43000 & 553 & 0.06 & 632 & 0.11 & 8.0 \\
\hline 8 & 527 & 18000 & 590 & 19200 & 600 & $<0.01$ & 748 & $\sim 0.01$ & 7.9 \\
\hline
\end{tabular}

All samples in aqueous phosphate/citric acid buffer containing 1\% DMSO. ${ }^{a}$ Data from Ref. 9. ${ }^{b}$ Emission too weak to determine. ${ }^{c}$ Not measurable in aqueous buffer. ${ }^{\mathrm{d}}$ Measured at $\mathrm{pH} 6 .{ }^{\mathrm{e}}$ Measured at $\mathrm{pH} 11$. 


\section{Acknowledgments}

This work was supported the by Novo Nordisk Foundation, Biotechnology Based Synthesis and Production Research

\section{References and notes}

1. Loudet, A.; Burgess, K. Chem. Rev. 2007; 107: 4891-4932.

2. Kobayashi, H.; Ogawa, M.; Alford, R.; Choyke, P. L.; Urano, Y. Chem. Rev. 2010; 110: 2620-2640.

3. de Silva, A. P.; Moody, T. S.; Wright, G. D. Analyst 2009; 134 (12): 2385-2393.

4. Han, J.; Burgess, K. Chem. Rev. 2010; 110: 2709-2728.

5. Azuma, E.; Nakamura, N.; Kuramochi, K.; Sasamori, T.; Tokitoh, N.; Sagami, I.; Tsubaki, K. J. Org. Chem. 2012; 77 (7): 34923500 .

6. Yang, Y.; Lowry, M.; Xu, X.; Escobedo, J. O.; Sibrian-Vazquez, M.; Wong, L.; Schowalter, C. M.; Jensen, T. J.; Fronczek, F. R.; Warner, I. M.; Strongin, R. M. Proc. Natl. Acad. Sci. U. S. A. 2008; 105 (26): 8829-8834.

7. Sibrian-Vazquez, M.; Escobedo, J. O.; Lowry, M.; Fronczek, F. R.; Strongin, R. M. J. Am. Chem. Soc. 2012; 134: 10502-10508.

8. Terai, T.; Nagano, T. Eur. J. Physiol. 2013; 465; 347-359.

9. Hammershøj, P.; Kumar, E. K. P.; Harris, P.; Andresen, T. L.; Clausen, M. H. Eur, J. Org. Chem. 2015; 7301-7309.

10. Yang, Y.; Lowry, M.; Schowalter, C. M.; Fakayode, S. O.; Escobedo, J. O.; Xu, X.; Zhang, H.; Jensen, T. J.; Fronczek, F. R.; Warner, I. M.; Strongin, R. M. J. Am. Chem. Soc. 2006; 128: 14081-14092.

11. Liu, J.; Diwu, Z.; Leung, W. Y. Bioorg. Med. Chem. Lett. 2001; 11 (22): 2903-2905.

12. Whitaker, J. E.; Haugland, R. P.; Prendergast, F. G. Anal. Biochem. 1991; 194: 330-344.

13. Fabian, W. M. F.; Schuppler, S.; Wolfbeis, O. S. J. Chem. Soc., Perkin Trans. 2 1996; 5: 853-856.

14. Lee, L. G.; Berry, G. M.; Chen, C. H. Cytometry 1989; 10 (2): 151-164.

15. Urano, Y.; Kamiya, M.; Kanda, K.; Ueno, T.; Hirose, K.; Nagano, T. J. Am. Chem. Soc. 2005; 127: 4888-4894.

16. Ueno, T.; Urano, Y.; Setsukinai, K.; Takakusa, H.; Kojima, H.; Kikuchi, K.; Ohkubo, K.; Fukuzumi, S.; Nagano, T. J. Am. Chem. Soc. 2004; 126: 14079-14085.

17. Hammersh $\varnothing$ j P.; Clausen, M. H. PCT Int. Appl. (2015), WO 2015169854 A1 2015111

18. General Procedure for the Synthesis of 5-Carboxy-SNAFLs. 4(2,4-Dihydroxybenzoyl)isophthalic acid (1) $(500 \mathrm{mg}, 1.65 \mathrm{mmol})$ and the appropriate dihydroxynaphthalene $(275 \mathrm{mg}, 1.75 \mathrm{mmol})$ were dissolved in methanesulfonic acid $(10 \mathrm{~mL})$ or a mixture of TFA ( $5 \mathrm{~mL})$ and methanesulfonic acid $(5 \mathrm{~mL})$, and stirred at room temperature overnight. The reaction was quenched with $\mathrm{H}_{2} \mathrm{O}(25$ $\mathrm{mL}$ ) and the resulting dark purple precipitate collected by centrifugation. After decantation, the precipitate was dissolved in $\mathrm{NaOH}(\mathrm{aq})(2 \mathrm{M}, 15 \mathrm{~mL})$ and precipitated with $\mathrm{HCl}(\mathrm{aq})(2 \mathrm{M}, 20$ $\mathrm{mL})$. After decantation, the precipitate was washed with $\mathrm{H}_{2} \mathrm{O}(2 \mathrm{x}$ $35 \mathrm{~mL})$, dissolved in EtOH (10 mL) and precipitated with $\mathrm{H}_{2} \mathrm{O}$. After decantation and washing with $\mathrm{H}_{2} \mathrm{O}(2 \times 35 \mathrm{~mL})$, the compound was dried in vacuo yielding a dark purple powder. If required, further purification by silica gel dry column vacuum chromatography $\left(2 \% \mathrm{AcOH}\right.$ in $\mathrm{CH}_{2} \mathrm{Cl}_{2} / \mathrm{MeOH}$ with $5 \%$ increments) was performed by dissolution of the compound in $\mathrm{MeOH}$ and $\mathrm{NaOH}(\mathrm{aq})$ (12 M, 2 drops) and evaporation onto Celite in vacuo.

19. Analytical data for a typical 5-carboxy-SNAFL (3). Starting from 2,3-dihydroxynaphthlene (54 mg, $331 \mu \mathrm{mol})$ and 4-(2,4dihydroxybenzoyl)isophthalic acid (1) $(100 \mathrm{mg}, 331 \mu \mathrm{mol})$. Purification by chromatography was necessary. Yield: $41 \mathrm{mg}$, 29\%; Mp: 205-208 ${ }^{\circ} \mathrm{C}$; ${ }^{1} \mathrm{H}$ NMR (400 MHz, acetone-d6) $\delta 9.15$ (broad s, $\mathrm{D}_{2} \mathrm{O}$ exchangeable $\left.\mathrm{OH}\right), 9.10$ (broad s, $\mathrm{D}_{2} \mathrm{O}$ exchangeable $\mathrm{OH}), 8.68(\mathrm{dd}, J=1.5,0.6 \mathrm{~Hz}, 1 \mathrm{H}), 8.34(\mathrm{dd}, J=$ $8.0,1.5 \mathrm{~Hz}, 1 \mathrm{H}), 7.76(\mathrm{~d}, J=8.0 \mathrm{~Hz}, 1 \mathrm{H}), 7.52(\mathrm{~s}, 1 \mathrm{H}), 7.42(\mathrm{dd}, J$ $=8.0,0.6 \mathrm{~Hz}, 1 \mathrm{H}), 7.28(\mathrm{ddd}, J=8.0,5.9,2.0 \mathrm{~Hz}, 1 \mathrm{H}), 7.11-$ $6.98(\mathrm{~m}, 2 \mathrm{H}), 6.97-6.91(\mathrm{~m}, 1 \mathrm{H}), 6.71-6.70(\mathrm{~m}, 2 \mathrm{H}) ;{ }^{13} \mathrm{C} \mathrm{NMR}$ (101 MHz, Acetone) $\delta 170.16,167.15,160.90,160.65,151.59$, $146.64,144.39,138.34,134.42,133.53,130.49$, 129.63, 129.10, 128.07, 127.31, 126.48, 126.22, 125.84, 125.01, 115.19, 114.98, $112.53,110.79,103.97,85.12 ; \mathrm{MS}\left(\mathrm{ESI}^{+}\right) \mathrm{m} / \mathrm{z}\left[\mathrm{M}+\mathrm{H}^{+}\right]$calcd for $\mathrm{C}_{25} \mathrm{H}_{14} \mathrm{O}_{7}^{+} 427.4$, found 427.1. HR-MS (ESI): $\mathrm{m} / \mathrm{z}\left[\mathrm{M}+\mathrm{H}^{+}\right]$calcd for $\mathrm{C}_{25} \mathrm{H}_{14} \mathrm{O}_{7}^{+} 427.0812$, found 427.0825 .
X-ray crystallographic data, synthesis procedures, and NMR spectra. 